\title{
"Assessing the level of environmental information disclosure by listed companies on the stock market in Vietnam"
}

\begin{tabular}{|c|c|}
\hline AUTHORS & $\begin{array}{l}\text { Thi Kim Tuyen Nguyen } \\
\text { Ngoc Tien Nguyen (D https://orcid.org/0000-0003-3998-9242 } \\
\text { Thi Mai Huong Nguyen }\end{array}$ \\
\hline ARTICLE INFO & $\begin{array}{l}\text { Thi Kim Tuyen Nguyen, Ngoc Tien Nguyen and Thi Mai Huong Nguyen (2019). } \\
\text { Assessing the level of environmental information disclosure by listed companies } \\
\text { on the stock market in Vietnam. Problems and Perspectives in Management, } \\
\text { 17(3), 207-217. doi:10.21511/ppm.17(3).2019.17 }\end{array}$ \\
\hline DOI & http://dx.doi.org/10.21511/ppm.17(3).2019.17 \\
\hline RELEASED ON & Wednesday, 21 August 2019 \\
\hline RECEIVED ON & Wednesday, 19 June 2019 \\
\hline ACCEPTED ON & Monday, 22 July 2019 \\
\hline LICENSE & $\begin{array}{l}(c) \text { EY } \\
\text { This work is licensed under a Creative Commons Attribution } 4.0 \text { International } \\
\text { License }\end{array}$ \\
\hline JOURNAL & "Problems and Perspectives in Management" \\
\hline ISSN PRINT & $1727-7051$ \\
\hline ISSN ONLINE & $1810-5467$ \\
\hline PUBLISHER & LLC "Consulting Publishing Company "Business Perspectives" \\
\hline FOUNDER & LLC "Consulting Publishing Company "Business Perspectives" \\
\hline
\end{tabular}

NUMBER OF REFERENCES

41

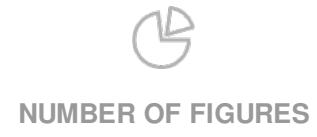

1
NUMBER OF TABLES

4

(C) The author(s) 2021. This publication is an open access article. 


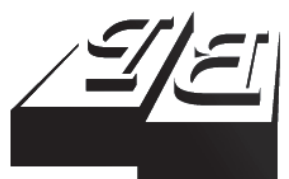

BUSINESS PERSPECTIVES

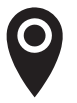

LLC "CPC "Business Perspectives" Hryhorii Skovoroda lane, 10, Sumy, 40022, Ukraine

www.businessperspectives.org

Received on: $19^{\text {th }}$ of June, 2019 Accepted on: 22nd of July, 2019

(c) Thi Kim Tuyen Nguyen, Ngoc Tien Nguyen, Thi Mai Huong Nguyen, 2019 of Economics \& Accounting, Quy Nhon University, Vietnam.

Ngoc Tien Nguyen, Ph.D., Faculty of University, Vietnam.

Thi Mai Huong Nguyen, Ph.D., University of Ho Chi Minh City, Vietnam.
Thi Kim Tuyen Nguyen, MA, Faculty Economics \& Accounting, Quy Nhon Faculty of Accounting, Banking

Thi Kim Tuyen Nguyen (Vietnam), Ngoc Tien Nguyen (Vietnam),

Thi Mai Huong Nguyen (Vietnam)

\section{ASSESSING THE LEVEL OF ENVIRONMENTAL INFORMATION DISCLOSURE BY LISTED COMPANIES ON THE STOCK MARKET IN VIETNAM}

\begin{abstract}
The environmental information disclosure of enterprises listed on Vietnam's stock market has been mandated by the Ministry of Finance of Vietnam according to Circular No. 155/2015/TT_BTC. Therefore, enterprises need to be responsible for announcing and interpreting financial and non-financial information about the environment to meet the needs of the Government and stakeholders. However, the level of environmental information disclosure depends on their business, company characteristics, compliance of the board of management, etc. This paper investigates and assesses the level of environmental information disclosure of the listed companies on the stock market in Vietnam. The study was conducted with 170 listed companies on the Hanoi Stock Exchange (HNX) and Ho Chi Minh City Stock Exchange (HOSE) through descriptive statistics and value testing methods and an in-depth interview. The research results have shown that in Vietnam, the level of enterprises announcing environmental information disclosure is still low. For example, materials and construction industry, food and beverage industry have less than $55 \%$ of enterprise disclosing environmental information. At the same time, the enterprises from environmentally sensitive sectors such as materials and construction, electricity, petroleum, gas, chemicals, etc., have more environmental information disclosure than other industries, and the environmental information published only focuses on the environmental debt, the amount of resources consumed, the number of environmental violations, environmental policies and objectives, etc.
\end{abstract}

Keywords

JEL Classification Vietnam

M14, M41, M48

\section{INTRODUCTION}

The environment is currently becoming a matter of concern of the local community, customers and investors. The Government of Vietnam implements the direction of sustainable growth and development for national economy, so the pressure to implement the responsibility of announcing and interpreting environmental information is also increasing gradually to meet different needs of stakeholders. Vietnamese enterprises have made moves to demonstrate their efforts through combining environmental values into their business operations, providing more environmental information in their reports to ensure the economic as well as environmental efficiency and start reporting on this issue with a tendency to ensure comprehensiveness, transparency, completeness, meeting international practices.

This is an Open Access article, Creative Commons Attribution 4.0 International license, which permits unrestricted re-use, distribution, and reproduction in any medium, provided the original work is properly cited.

The published environmental information is presented in financial statements, annual reports or in a separate sustainability report. The disclosure of environmental information is part of social responsibil- 
ity report or sustainable growth report of an organization to meet the requirements of stakeholders (Hahn \& Kühnen, 2013; Chaklader \& Gulati, 2015). Corporate environmental reporting has been mainly a phenomenon of developed countries and consequently, most corporate environmental reporting studies were confined to the developed countries (Belal, 2000). A handful of studies concentrated on the newly industrialized countries such as Korea, Hong Kong, Malaysia and Singapore, and African countries such as South Africa, Nigeria and Uganda (Belal, 2000).

In Vietnam, there are quite a few practical studies on environmental information disclosure of enterprises. Hoang (2013) conducted a study of environmental financial accounting of listed companies and found 72 enterprises equivalent to $12 \%$ of the sample size published environmental information. The environmental costs and environmental liabilities are the main published information. Meanwhile, no enterprise has published qualitative information about the environment such as policies, objectives and environmental strategies of enterprises. By 2015, the Ministry of Finance of Vietnam has issued regulations on environmental information disclosure for listed companies on the stock market through Circular No. 155/2015/TT_BTC, required enterprises to announce such as: quantity of materials, water, energy used, number of times of environmental regulations violation, etc. Thence, studies on environmental information disclosure in Vietnam are conducted but these studies mainly consider the perspective of factors affecting environmental information disclosure. There are no studies on assessing the level of environmental information disclosure of enterprises. While high or low level of environmental information disclosure of an enterprise directly affects information transparency and corporate social responsibility. Therefore, the purpose of this paper is to assess the level of environmental information disclosure by listed companies in Vietnam through annual reports. This paper was made to fit into the current research gap in the environmental information disclosure in Vietnam; and it is really useful for a developing country towards environmental sustainability like Vietnam.

The rest of this paper is organized as follows: the next section presents clearly the research overview. Research methods include describing research variables, the way to collect and process data. Then, the article presents the research results, including descriptive statistics on the level of environmental information disclosure and discusses the research results. The final part concludes the research and demonstrates the limitations and directions for future research.

\section{RESEARCH OVERVIEW}

According to Mathews (2000), environmental accounting studies focused mainly on environmental information disclosure in the late 1990s. The environmental information disclosure has become an issue of great interest from international organizations, countries and domestic and foreign researchers in both aspects of professional/academic research and practical research.

From a professional/academic research standpoint: UN Conference on Trade and Development (UNCTAD) (2002) provides conditions for recognition, measurement and publication of the elements of financial statements relating to environmental issues such as environmental costs, environmental and asset liabilities. In addition to, The
United States Environmental Protection Agency (USEPA) (1995), United Nations Division of Sustainable Development (UNDSD) (2001), Japan Ministry of the Environment (JMOE) (2005) and International Federation of Accountants (IFAC) (2005) also issued guidelines, specifying the definition of environmental income and the list of environmental costs.

From a practical research point of view, there are many researchers who are interested in this issue. Environmental information disclosure is the subject of research in developed countries (Belal, 2000). This research trend has expanded to developing countries (Sumiani et al., 2007; Ann, 2012; Zhang, 2018; Linh, 2019). Research group summarizes studies on environmental information disclosure in some countries according to the timeline. 
Niskala and Pretes (1995) studied on 75 of the largest companies in Finland's environmentally sensitive industries from 1987 to 1992 and showed significant changes of environmental information disclosure in mid-year 1987 and 1992. In 1992, nearly 50\% of research companies provided environmental information in annual reports, while in 1987 the figure was $25 \%$. Moneva and Liena (2000) analyze the environmental information disclosure in annual reports of environmentally sensitive companies in Spain on the basis of stakeholder theory and have shown a number of quantity aspects and quality in environmental reports during 1992-1994.

Salomone and Galluccio (2001) examined annual reports of 82 petroleum and chemical companies from 1993 to 1998, specifically 26 companies in the US and Canada, 26 companies in Northern Europe, 26 companies in the South Europe and 4 companies from other countries. The authors have shown that $92.1 \%$ of selected companies have published environmental information in their annual reports; in which $100 \%$ of companies from the United States or Canada are subject to strict environmental regulations, followed by $96.2 \%$ from the Northern Europe, and finally Southern European countries still have quite high rate of publication of $86.8 \%$, despite few environmental regulations. The research results indicate that the environmental information in the annual reports is classified into two categories: qualitative information and quantitative information. The most common qualitative information is environmental policy $(68.29 \%)$, followed by environmental management system (41.46\%), green products (39.02\%), environmental objectives (37.8\%), environmental certification (32.93\%), staff training (18.29\%), environmental audit (18.29\%), environmental messages (18.29\%). The most common environmental quantitative information is environmental liabilities (58.54\%) because most national and international accounting standards require this information disclosure, and environmental costs (51.22\%). The study also explained that there are differences between companies and countries in environmental information disclosure, so information is incomparable.

Sumiani et al. (2007) conducted a study of 50 Malaysia's leading public companies from various industries listed on the Bursa Malaysia Stock Exchange in 2003. The results show that the level of environmental information disclosure in the annual reports of the companies in Malaysia is quite low, showing general information or qualitative information. The study also found that the ISO certificate of environmental management system has an impact on voluntary environmental information disclosures.

Zhang et al. (2008) conducted a practical study of 384 annual reports of 128 Chinese listed chemical companies in three years from 2003 to 2005 - before the new Accounting Standard came into effect for Chinese listed companies. Up to $61.5 \%$ of companies in the research sample have practiced environmental information disclosure, the number of enterprises announced increased from 73 companies (equivalent to $52.90 \%$ ) in 2003 to 95 companies (equivalent to $68.84 \%$ ) in 2005 and more diversified published environmental information, mostly non-financial information. The research also shows that investors do not rely on the annual reports and require mandatory regulations and policies on environmental information and corporate social responsibility.

From data of 110 enterprises of nine Chinese industries listed, Ane (2012) showed that the rate of environmental information disclosure increased from $66.36 \%$ in 2007 to $83.63 \%$ in 2009 . In three years, there are 47 enterprises $(42.73 \%)$ disclosed environmental information continually, 18 enterprises (16.37\%) do not disclose. Most of the environmental information was qualitative information and quantitative information was limited. Forty percent of companies disclosed environmental reporting in less than 100 words. Many companies disclosed environmental pollution control costs and environmental management costs. Environmental information disclosed was historic and that impacted future development was disclosed scarcely.

Zhang (2018) studied environmental accounting information disclosure in China's oil and gas industry for 2007-2017. Research results showed that the number of environmental information disclosed has increased. Environmental information disclosure included seven aspects: environmental assets, environmental costs, environmental liabilities, environmental income, environmental protection policies, energy consumption and discharge, treatment of pollutants.

In Vietnam, Nguyen (2012) studies the organization of environmental cost accounting for Beer-Alcohol- 
Beverage enterprises in the Southern key economic region, showing no environmental income, average environmental costs is less than VND 100 million (accounting for 58.1\%), from VND 100 million to VND 500 million (accounting for $25.8 \%$ ), over VND 500 million (accounting for 16.1\%). All enterprises recorded the environmental costs into product costs through account No. 627 but found no information related to environmental costs when published. Hoang's (2013) research on Environmental Financial Accounting and the orientation to apply in Vietnam has shown that 72 out of 593 enterprises have published environmental information on annual reports in 2012; however, the environmental information is presented unjointly and interspersed with other information, making it difficult to find and evaluate. The published information has no environmental qualitative information but only quantitative information, and the environmental information does not meet the needs of users, does not receive support from enterprises' managers. Pham (2016) researches on completing the organization of environmental accounting work in manufacturing enterprises in Quang Ngai province in four sectors: mechanics, metallurgy; food and beverage processing; agro-processing industry; and chemical industry. The author shows that accounts of assets, liabilities, environmental costs and income are reflected in traditional financial accounting; environmental costs, which stand for specific industry groups, are reflected in general production costs, business management costs, other costs, etc. Therefore, it is recommended that the environmental information should be presented in a separate part on the financial statement explanation.

Nguyen et al. (2017) studied 74 listed construction enterprises on Vietnam Stock Exchange for the period from 2013 to 2016. The results indicated that the disclosure level of environmental accounting information of construction firms tends to increase, especially in 2016. This showed that construction companies in Vietnam are paying attention to guidance of Circular No. 155/2015/TT-BTC issued by the Ministry of Finance. Two groups of information elements mostly disclosed by listed firms are information on the environmental complaint mechanism and information on label of products and services. However, some important fields receiving special concerns from stakeholders have lower score, for example energy, emissions, wastewater and waste.

According to Linh (2019), Vietnamese aquaculture enterprises disclosed general environment information but they did not disclose environment accounting information, since balance sheets and income statements did not present any environment accounting information. Firms have presented information on environmental management investment on notes of financial statements such as: construction of farming, waste treatment systems, environmental liabilities (taxes, fees, compensation).

\section{RESEARCH METHOD}

\subsection{Description of the observed variables}

Based on Circular No. 155/2015/TT-BTC issued by the Ministry of Finance of Vietnam and inheriting previous studies with expert advice in accordance with the context of Vietnam, the authors designed the variables to closely measure the level of environmental information disclosure with a 5-point Likert scale (with 1 "completely disagree" and 5 "fully agree") (see Table 1).

Table 1. Observed variables measuring the level of environmental information reporting

\begin{tabular}{|c|c|c|}
\hline Observed variables & Code & Resource \\
\hline 1. Consumption of resources: raw materials, water, energy, ... & EID 1 & Circular 155/2015/TT-BTC, GRI (G4-2013) \\
\hline 2. The number of times the environmental regulation is violated & EID 2 & Circular 155/2015/TT-BTC, GRI (G4-2013) \\
\hline 3. Policy, target, environmental quality & EID 3 & UNCTAD (2002), Wiseman (1982), Zeng et al. $(2005,2010,2012)$ \\
\hline 4. Environmental management system - ISO 14001 & EID 4 & Zeng et al. $(2010,2012)$ \\
\hline 5. Environmental costs & EID 5 & UNCTAD (2002), IFAC (2005), GRI (G4-2013), Liu et al. (2009) \\
\hline 6. Environmental liabilities & EID 6 & $\begin{array}{l}\text { Law on Natural Resources Tax (2009), Law Mineral (2010), IAS } \\
\text { 37, IFRS 6, UNCTAD (2002), Wiseman (1982) }\end{array}$ \\
\hline 7. Environmental assets & EID 7 & $\begin{array}{l}\text { UNCTAD (2002), IAS 16, IAS 38, Zeng et al. (2010, 2012), Liu et } \\
\text { al. (2009) }\end{array}$ \\
\hline 8. Environmental income, revenue & EID 8 & UNCTAD (2002), IAS 20, Hoang (2013) \\
\hline
\end{tabular}




\subsection{The way to collect data}

To meet the research objectives, the authors have collected data from two sources: primary data and secondary data.

\subsubsection{Primary data collection}

To assess the level of environmental information disclosure, the authors use the questionnaire survey method, send it directly or via google form tool to accountants, chief accountants, directors at listed companies on the Vietnamese stock market. The survey forms consist of two parts. Part 1 deals with general information of respondents and part 2 contains survey questions. The survey questions are designed around research objectives, requiring respondents to evaluate, based on Likert scale from 1 to 5 , with 1 being completely disagree and 5 being fully agree.

In order to have an official survey form, the survey was carried out in three phases. Phase 1 is to prepare draft survey form. Based on the research overview, the authors obtained the initial survey form. Phase 2 is to consult with experts and conduct a preliminary survey to ensure that the questions in the survey are adequate and relevant to the Vietnamese context. The research team conducted in-depth interviews with senior lecturers at universities as well as auditors and conducted a preliminary survey with a sample of 10 listed companies on the Vietnamese stock market. The results show that the questionnaire needs to be added with the concepts of "environmental assets, environmental liabilities, environmental income, environmental uncertainty", so that the survey objects can be clearly identified. Phase 3 is to design the official questionnaire. Based on the phase 2 results, the authors synthesized and produced the final questionnaire to be sent to the respondents of 170 listed companies in the stock market in Vietnam.

\subsubsection{Secondary data collection}

To assess the level of environmental information disclosure, the research team collected the 2017 annual reports of 170 listed companies on the Vietnamese stock market. This research sample is taken from Industry Classification Benchmark
(2017) data by stratified method into eight environmentally sensitive industries based on Circular 04/2012/TT_BTNMT, including: 14 enterprises in utilities, gas, oil and gas; nine enterprises in tourism and entertainment industry; 16 enterprises of chemical industry; 24 enterprises of basic resources industry; 24 enterprises of food and beverage industry; 70 enterprises in construction and materials industry; nine enterprises of medical industry; and four enterprises of automobile spare parts industry. Then, the eight published environmental information components that the research team mentioned in Table 1 are examined, evaluated and discussed.

\subsection{Method of data analysis}

\subsubsection{Analysis of primary data}

SPSS 22.0 software was used to analyze primary data through descriptive statistics and value testing tools.

\subsubsection{Analysis of secondary data}

The authors use the published index method to measure the level of environmental information disclosure. This approach was applied by writing some items to the environmental information items and using the direct method or the weighting method to calculate the total points. This study uses direct index method, which is done in two steps. Firstly, points are calculated for each type of environmental information disclosure by using the encryption tool in the same way as Wiseman (1982). Each type of environmental information is recorded according to the score level and the score ranges from 0 to 3 , of which 3 is for quantitative information, 2 for qualitative information with specific content, 1 for general qualitative information and 0 no information (Wiseman, 1982). Secondly, points for each enterprise's level of environmental information disclosure are calculated according to the following equation:

$$
\operatorname{SEID}_{i}=\sum_{j}^{n} S C I D_{i j}
$$

where $S E I D_{i}$ is the total score of $S E I D$ for the $i$-th enterprise, where $i=1,2, \ldots, 170$ enterprise and $S C I D_{i j}$ are the points of the $j$-th component for the $i$ - th enterprise, where $j=1,2, \ldots, 8$. In the 
analysis, dummy variables are firstly constructed to reveal if there is environmental information or not: 0 if $S E I D_{i}$ is equal to 0 and 1 otherwise. After that, attention is paid to the enterprises with $S E I D_{i}$ greater than 0 and $S E I D_{i}$ value is used as a measure of the level of environmental information disclosure. To ensure consistency among companies, all the individual points of environmental information published have been reviewed independently. All disagreements were then reviewed by the research team later.

\section{RESEARCH RESULT}

The scope of the research is the listed companies on the Vietnam stock market. Based on Industry Classification Benchmark data (2017), the authors have selected the research sample. To ensure high representativeness and generalization of the sample, the authors decided to use probability sampling method with stratified sampling technique. In other words, the research sample will have a proportion corresponding to the overall and be divided by eight industries sensitive to the environment on the basis of Circular 04/2012/ TT_BTNMT, including: utilities, petroleum and gas; tourism and entertainment industry; chemical industry; basic resources industry; food and beverage industry; construction and materials industry; medical industry; automotive parts industry. After that, the authors used the technique of probability sampling to determine the number of enterprises in each industry to ensure the specificity of the whole, expressing the business characteristics such as: total assets, number of employees, types of enterprises. The number of enterprises separated by industry in the sample is shown in detail in Table 2.

Table 2 shows that, in terms of the proportion of environmental information disclosure, tourism and entertainment enterprises, automobiles and spare parts have a $100 \%$ disclosure proportion; retilities, petroleum and gas industry has the disclosed rate of $85.7 \%$; basic resource industry has the rate of $79.2 \%$, health sector is at the rate of $66.7 \%$; chemical industry is at the rate of $62.5 \%$; and the lowest are the materials and construction industry (54.3\%) and the food and beverage industry (54.2\%). Therefrom, in Vietnam, environmentally sensitive industries have a higher proportion of enterprises disclosing environmental information than businesses that are less sensitive to the environment. At the same time, out of 111 enterprises that have implemented environmental information disclosure in the 2017 annual report, there are 38 materials and construction enterprises (with the rate of 34.2\%), 19 basic resource enterprises (17.1\%), 13 enterprises of food and beverage (11.7\%), 12 enterprises of utilities, petroleum and gas $(10.8 \%), 10$ chemical enterprises $(9.0 \%)$, nine tourism and entertainment enterprises (8.1\%), six medical enterprises (5.4\%), and four automobile and spare parts enterprises (3.6\%). Therefore, in Vietnam, two industries with the highest percentage of environmental information disclosure are tourism and entertainment and automobile and spare parts (percentage of $100 \%$ ), the third is utilities, petroleum and gas (85.7\%) and the industry with the lowest published rate is the food and beverage industry (proportion of 54.2\%).

Table 2. Industry distribution in the research sample

Source: Collected by the authors.

\begin{tabular}{|c|c|c|c|c|c|}
\hline \multirow[t]{2}{*}{ Industry } & \multicolumn{2}{|c|}{ Enterprises } & \multicolumn{2}{|c|}{$\begin{array}{c}\text { Environmental information } \\
\text { disclosure enterprises }\end{array}$} & \multirow{2}{*}{$\begin{array}{c}\text { Ratio of } \\
\text { disclosure (\%) }\end{array}$} \\
\hline & Quantity & Proportion (\%) & Quantity & Proportion (\%) & \\
\hline 1. Utilities, petroleum and gas & 14 & 8.2 & 12 & 10.8 & 85.7 \\
\hline 2. Tourism and entertainment & 9 & 5.3 & 9 & 8.1 & 100 \\
\hline 3. Chemical & 16 & 9.4 & 10 & 9.0 & 62.5 \\
\hline 4. Basic resourses & 24 & 14.1 & 19 & 17.1 & 79.2 \\
\hline 5. Food and beverage & 24 & 14.1 & 13 & 11.7 & 54.2 \\
\hline 6. Material and construction & 70 & 41.2 & 38 & 34.2 & 54.3 \\
\hline 7. Medical industry & 9 & 5.3 & 6 & 5.4 & 66.7 \\
\hline 8. Automobile and spare parts & 4 & 2.4 & 4 & 3.6 & 100 \\
\hline Total & 170 & 100 & 111 & 100 & \\
\hline
\end{tabular}


Automobile and spare parts enterprises

Medical enterprises

Materials and construction enterprises

Enterprises of food and beverage

Basic resource enterprises

Chemical enterprises

Tourism and entertainment enterprises

Enterprises of utilities, petroleum, gas

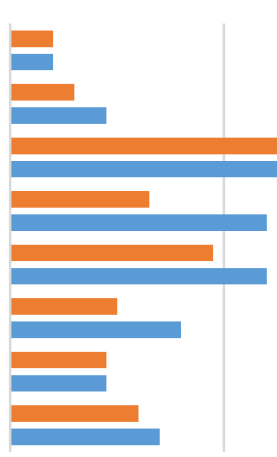

\begin{abstract}
$0 \quad 20$
$20 \quad 40$

Number of businesses

Number of enterprises announcing environmental information

Figure 1. Statistics of enterprises with environmental information disclosure compared to surveyed enterprises
\end{abstract}

According to Figure 1, among the industries, the materials and construction industry has the lowest number of enterprises implementing disclosure as compared to the total number of surveyed enterprises (38 compared to 70 enterprises) although the level of environmental information disclosure of this sector is the highest among all surveyed sectors, followed by food and beverage (13 compared to 24 enterprises) and chemicals (10 compared to 16 enterprises).

However, in terms of the level of environmental information disclosure by industry, there are four groups of sectors with the high point. Utilities, petroleum, and gas industry (production and distribution of utilities, gas) has the highest level of significance ( 7.36 points), followed by the automobile and spare parts industry (automobile manufactur- ing and automotive parts) with a significant level of 5.0 points. Basic resources sector (paper production, mining, metals) has the 3.71 points level of significance, Materials and construction (production of bricks, concrete, cement, etc.) enterprises have the level of significance of 3.56 points. The industry with the lowest level of environmental information disclosure is the health sector with a significance level of 1.89 points. This indicates that the Government of Vietnam has made great efforts in establishing laws to control sensitive industries in recent years, so the more environmentally sensitive sectors are, the more environment information disclosure must be implemented, and the higher level of environmental information disclosure must take place. Table 3 presents the level of environmental information disclosure according to industries in Vietnam.

Table 3. The results for the level of environmental information reporting by industries

Source: Result of SPSS 22.0.

\begin{tabular}{|c|c|c|c|c|c|c|}
\hline Industry & SEID & Mean & Max & Min & $\begin{array}{c}\text { Standard } \\
\text { error of mean }\end{array}$ & $\begin{array}{l}\text { Standard } \\
\text { deviation }\end{array}$ \\
\hline 1. Electricity, water, petroleum, gas & 103 & 7.36 & 13 & 0 & 1.291 & 4.830 \\
\hline 2. Tourism and entertainment & 19 & 2.11 & 3 & 1 & 0.309 & 0.928 \\
\hline 3. Chemical & 57 & 3.56 & 11 & 0 & 0.987 & 3.949 \\
\hline 4. Basic resources & 89 & 3.71 & 18 & 0 & 0.890 & 4.359 \\
\hline 5. Food and beverage & 37 & 1.54 & 6 & 0 & 0.356 & 1.744 \\
\hline 6. Construction materials & 169 & 2.41 & 12 & 0 & 0.380 & 3.183 \\
\hline 7. Medical & 17 & 1.89 & 6 & 0 & 0.696 & 2.088 \\
\hline 8. Automobile, spare parts & 20 & 5.00 & 7 & 1 & 1.354 & 2.708 \\
\hline
\end{tabular}


Table 4. Summary of components of published environmental information

Source: Result of SPSS 22.0.

\begin{tabular}{|c|c|c|c|c|c|c|}
\hline Component & SEID & Mean & Maximum & Minimum & Standard error of mean & Standard deviation \\
\hline EID 1 & 127.0 & 0.7 & 2.0 & 0.0 & 0.1 & 1.0 \\
\hline EID 2 & 60.0 & 0.4 & 2.0 & 0.0 & 0.0 & 0.5 \\
\hline EID 3 & 56.0 & 0.3 & 1.0 & 0.0 & 0.0 & 0.5 \\
\hline EID 4 & 19.0 & 0.1 & 1.0 & 0.0 & 0.0 & 0.3 \\
\hline EID 5 & 18.0 & 0.1 & 3.0 & 0.0 & 0.0 & 0.6 \\
\hline EID 6 & 195.0 & 1.1 & 9.0 & 0.0 & 0.2 & 2.1 \\
\hline EID 7 & 33.0 & 0.2 & 6.0 & 0.0 & 0.1 & 0.9 \\
\hline EID 8 & 3.0 & 0.0 & 3.0 & 0.0 & 0.0 & 0.2 \\
\hline
\end{tabular}

The eight components of environmental information disclosure according to Circular 04/2012/TT BTNMT have been checked by the research team and shown in Table 4. The results show that the qualitative environmental information (from EID 1 to EID 4) and quantitative environmental information (from EID 5 to EID 8) has been published by Vietnamese listed enterprises on the Vietnamese stock market in the annual reports to meet the legal requirements of the State Securities Commission and the Ministry of Finance. The environmental information has differences in levels between enterprises and industries. This demonstrates the selection behavior of EID of listed companies in the research. EID is used to legalize the sensitive nature of business operations with environmental issues rather than providing environmental information to meet the needs of stakeholders.

According to Table 4, environmental information (SEID column) is published mainly in the aspects below.

- The EID 6 (environmental liabilities) is ranked first, with $S E I D=195.0$. Most of the information of environmental liabilities is natural resource tax, environmental protection tax, and environmental rehabilitation. This demonstrates the strategy of EID of listed companies towards meeting the government's environmental concerns through a series of mandatory regulations.

- The EID 1 (the amount of resources consumed) is ranked second, with $S E I D=127.0$. Most enterprises have clearly shown the amount of materials, water and energy used for production and business activities in the period as required in Circular 155/2015/TT-BTC.
The EID 2 (the number of environmental violation fines) is ranked third, with SEID $=60.0$. In this context, it shows that almost all enterprises have complied with all relevant environmental regulations, only one enterprise shows the fine for violating this environmental regulation.

- The EID 3 (environmental policies and objectives) is ranked fourth, with $S E I D=56.0$, showing the principles and measures for economical use of natural resources, reducing waste, improving environmental protection initiatives of enterprises. This is evident in large-scale enterprises such as Petrovietnam Gas Joint Stock Corporation, CNG Vietnam Joint Stock Company, etc.

- The EID7 (environmental assets) is ranked fifth, with $S E I D=33.0$. It shows the information about waste and emission treatment projects or environmental deposits. This reflects the awareness of environmental protection of listed enterprises has been improved in Vietnam.

- The EID 4 (environmental management system) is ranked sixth, with $S E I D=19.0$. With variability, uncertainty and environmental risks, the enterprises are increasingly interested in investing in environmental management systems.

- The EID 5 (environmental cost) is ranked seventh, with $S E I D=18.0$ reflecting the arising environmental costs associated with the characteristics of production and business activities such as risk costs for environmental damage compensation, contingency for environmental risks, fees for environmental violations, etc. 
- The EID 8 (environmental income) has the lowest level of EID, with SEID $=3.0$ representing the income from the sale of waste. Most enterprises believe that there is no environmental income.

In summary, the annual report of listed companies on the Vietnamese stock market mainly publishes mandatory environmental information, especially accounting for a large proportion of environmental liabilities, environmental costs. The published environmental information is mostly positive information rather than negative information, mainly from the state's legal regulations related to environmental issues.

\section{RESEARCH RESULT DISCUSSION}

From the above research results, the level of environmental information disclosure of listed companies on the Vietnamese stock market is still low. Among 170 surveyed enterprises, only 111 ones conduct environmental information disclosure. Some enterprises in materials and construction, food and beverages account for less than $55 \%$ of those disclosing environmental information. The process of an in-depth interview was due to the fact that many enterprises are still not interested in environmental information disclosure activities, managers still worry about the disclosure of environmental information, they are afraid this will create a negative effect on their business operations. At the same time, the research results also show that the disclosure of environmental information is different between industries. The more sensitive industry to the environment will have more environmental information published in the annual report. The results of this study point to the level of environmental information disclosure of the construction materials, utilities, petroleum gas and basic resources, which have the highest levels of environmental information disclosure. These are also the most sensitive industries as stipulated in Circular 04/2012/ TT-BTNMT on identifying facilities causing environmental pollution. This continues to contribute to the results of previous studies suggesting that sensitive industry is a significant influence on environmental information disclosure (Patten, 1992; Roberts, 1992; Deegan \& Gordon, 1996; Cormier \& Gordon, 2001; Liu \& Anbumozhi, 2009; Malarvizhi \& Ranjani Matta, 2016). At the same time, the most published environmental information is environmental liabilities (such as natural resources tax, environmental protection tax, etc.), the amount of resources consumed, the number of environmental violations, environmental policies and objectives to meet mandatory regulations from the government and state management agencies related to production and business activities of enterprises. An in-depth interview has revealed that most enterprises believe that there is no environmental income, so this is the least published environmental information, reflecting the income from the sale of waste. Most enterprises consider environmental information disclosure as a mandatory task to comply with state legal documents, with few enterprises focusing on transparency of information or investment attraction.

\section{CONCLUSION}

This study examines the level of environmental information disclosure of listed companies on the Vietnamese stock market. Based on the study of 170 listed companies, the results show that the level of environmental information disclosure in Vietnam is still low. There are three sectors with a high level of environmental awareness: Construction materials (production of bricks, concrete, cement, etc); utilities, petroleum and gas (production and distribution of electricity, water, gas) and basic resources (paper production, mining, metals). The environmental information published is mainly environmental liabilities, the amount of resources consumed, the number of times of environmental violations and environmental policies and objectives. Since then, in addition to issuing regulations on environmental accounting and complying with environmental regulations, the Government of Vietnam needs to implement propaganda to raise awareness of environmental information disclosure for enterprises and issuing strong administrative sanctions enough to promote the environmental information disclosure 
by listed companies on the Vietnamese stock market. It is recognized that with an analytical database for only one year and only using annual reports it is not possible to obtain a general and firm conclusion about the level of environmental information disclosure. However, it is believed that this study contributed to general research of environmental information disclosure because it provided a view of environmental information disclosure activities in Vietnam. In addition, it is reasonable to suppose that the results of the research can be considered as a starting point for other future studies when extending the study period or studying the factors that affect environmental information disclosure in Vietnam.

\section{REFERENCES}

1. Ane, P. (2012). An assessment of the quality of environmental information disclosure of corporation in China. Systems Engineering Procedia, 5, 420426. https://doi.org/10.1016/j. sepro.2012.04.064

2. Belal, A. R. (2000). Environmental reporting in developing countries: empirical evidence from Bangladesh. Eco-Management and Auditing: The Journal of Corporate Environmental Management, 7(3), 114-121. https://doi.org/10.1002/10990925(200009)7:3\%3C114::AIDEMA131\%3E3.0.CO;2-E

3. Chaklader, B., \& Gulati, P. A. (2015). A study of corporate environmental disclosure practices of companies doing business in India. Global Business Review, 16(2), 321-335. https://doi.org/10.1177\%2F0972150914564430

4. Cormier, D., \& Gordon, I. M. (2001). An examination of social and environmental reporting strategies. Accounting, Auditing \& Accountability Journal, 14(5), 587-617. https://doi.org/10.1108/ EUM0000000006264

5. Deegan, C., \& Gordon, B. (1996). A study of the environmental disclosure practices of Australian corporations. Accounting and business research, 26(3), 187-199. https://doi.org/10.1080/00014788. 1996.9729510

6. Global Reporting Initiative (GRI). (2013). Sustainability reporting guidelines G4.

7. Hahn, R., \& Kühnen, M. (2013). Determinants of sustainability reporting: a review of results, trends, theory, and opportunities in an expanding field of research.
Journal of Cleaner Production, 59, 5-21. https://doi.org/10.1016/j. jclepro.2013.07.005

8. Hoang Thuy Dieu Linh. (2013). Financial and environmental accounting and application orientation in Vietnam (Master thesis), Ho Chi Minh City University of Economics, Ho Chi Minh City.

9. IFAC. (2005). International Guidance Document: EMA. New York.

10. Industry Classification Benchmark. (2017). Industry Classification Taxonomy.

11. International Accounting Standards Board. (2001). International Accounting Standard (IAS 37) Provisions, Contingent Liabilities and Contingent Assets.

12. International Accounting Standards Board. (2003). International Accounting Standard (IAS 16) Property, Plant and Equipment.

13. International Accounting Standards Board. (2004a). International Accounting Standard (IAS 38) Intangible Assets.

14. International Accounting Standards Board. (2004b). International Financial Reporting Standards (IFRS 6) Exploration for and Evaluation of Mineral Resources.

15. International Accounting Standards Board. (2009). International Accounting Standard (IAS 20) Accounting for Government Grants and Disclosure of Government Assistance.
16. Japan Ministry of the Environment. (2005). Environmental Accounting Guidelines.

17. Lam, T. T. L. (2019). Factors affecting Disclosure of environmental accounting information in Vietnamese aquaculture enterprises (Doctoral dissertation). Ho Chi Minh City University of Economics, Ho Chi Minh City.

18. Liu, X., \& Anbumozhi, V. (2009). Determinant factors of corporate environmental information disclosure: an empirical study of Chinese listed companies. Journal of Cleaner Production, 17(6), 593-600. https://doi.org/10.1016/j. jclepro.2008.10.001

19. Malarvizhi, P., \& Matta, R. (2016). Link between Corporate Environmental Disclosure and Firm Performance. Perception or Reality? The British Accounting Review, 36(1), 107-117.

20. Mathews, M. R. (2000). The development of social and environmental accounting research 1995-2000 (pp. 1-47). Retrieved from https://mro.massey.ac.nz/ handle/10179/2548

21. Ministry of Finance. (2015, October). Circular 155/2015/TTBTC guiding information disclosure on the stock market. Hanoi.

22. Ministry of Natural Resources and Environment. (2012). Circular No. 04/2012/TTBTNMT prescribing criteria for determining establishments causing environmental pollution, causing serious environmental pollution on May 8, 2012. Hanoi.

23. Moneva, J. M., \& Liena, F. (2000). Environmental disclosures in the 
annual reports of large companies in Spain. European Accounting Review, 9(1), 7-29. https://doi. org/10.1080/096381800407923

24. National Assembly. (2009, November). Resource tax law No. 45/2009/QH12. Hanoi.

25. National Assembly. (2010, November). Mineral Law No. 60/2010/QH12. Hanoi.

26. Nguyen Thanh Tai. (2012). Organizing the accounting of environmental costs for enterprises of Wine - Beer-Beverage in the southern key economic region (Master thesis). Ho Chi Minh City University of Economics.

27. Nguyen, L. S., Tran, M. D., Nguyen, T. X. H., \& Le, Q. H. (2017). Factors Affecting Disclosure Levels of Environmental Accounting Information: The Case of Vietnam. Accounting and Finance Research, 6(4), 255-264. https://doi. org/10.5430/afr.v6n4p255

28. Niskala, M., \& Pretes, M. (1995). Environmental reporting in Finland: a note on the use of annual reports. Accounting, Organizations and Society, 20(6), 457-466. https://doi.org/10.1016/03613682(94)00032-Q

29. Patten, D. M. (1992). Intra-industry environmental disclosures in response to the Alaskan oil spill: a note on legitimacy theory. Accounting, Organizations and Society, 17(5), 471-475. https://doi. org/10.1016/0361-3682(92)90042-Q

30. Pham Hoai Nam. (2016). Completing the organization of environmental accounting in manufacturing enterprises in Quang Ngai province (Doctoral dissertation). Academy of Finance, Hanoi.

31. Roberts, R. W. (1992).

Determinants of corporate social responsibility disclosure: An application of stakeholder theory. Accounting, Organizations and Society, 17(6), 595-612. https://doi. org/10.1016/0361-3682(92)90015-K

32. Robertson, D. C., \& Nicholson, N. (1996). Expressions of corporate social responsibility in UK firms. Journal of Business Ethics, 15(10), 1095-1106. Retrieved from https:// link.springer.com/article/10.1007/ BF00412050

33. Salomone, R., \& Galluccio, G. (2001). Environmental issues and financial reporting trends: a survey in the chemical and oil \& gas industries. Retrieved from https:// papers.ssrn.com/sol3/papers. cfm?abstract_id $=278240$

34. Sumiani, Y., Haslinda, Y., \& Lehman, G. (2007). Environmental reporting in a developing country: a case study on status and implementation in Malaysia. Journal of Cleaner Production, 15(10), 895-901. https://doi.org/10.1016/j. jclepro.2006.01.012

35. United Nations Conference on Trade and Development. (2002). Guidance manual accounting and financial reporting for environmental costs and liabilities. Geneva.

36. United Nations Division for Sustainable Development. (2001). Environmental Management Accounting Procedures and Principle. New York.
37. United States Environmental Protection Agency. (1995). An Introduction to Environmental Accounting as A Business Management Tool: Key Concepts and Terms, EPA 742-R-95-001. Office of Pollution Environmental Protection Prevention and Toxics Agency (MC 7409), Washington, D.C.

38. Wiseman, J. (1982). An evaluation of environmental disclosures made in corporate annual reports. Accounting, Organizations and Society, 7(1), 53-63. https://doi. org/10.1016/0361-3682(82)90025-3

39. Zeng, S. X., Xu, X. D., Yin, H. T., \& Tam, C. M. (2012). Factors that Drive Chinese Listed Companies in Voluntary Disclosure of Environmental Information. Journal of Business Ethics, 109(3), 309-321. Retrieved from https:// link.springer.com/article/10.1007/ s10551-011-1129-x

40. Zhang, J., Guo, H. T., Li, B., \& Wang, W. (2008). The Influence of Financial Factors on Environmental Information Disclosure in China Chemical Industry (pp. 1-12). Retrieved from https://papers.ssrn. $\mathrm{com} / \mathrm{sol} 3 /$ papers.cfm?abstract $\mathrm{id}=1305005$

41. Zhang. L. (2018). Research on Enterprise Environmental Accounting Information Disclosure from the Perspective of Environmental Protection - Taking Sinopec as an Example. Materials Science and Engineering, 452(3), 1-5. Retrieved from https://iopscience. iop.org/article/10.1088/1757899X/452/3/032022/pdf 